\title{
Industrial parks as an effective instrument of regional investment policy
}

\author{
Andrey Plakhin ${ }^{a}$, Ekaterina Ogorodnikova ${ }^{b}$ and Mikhail Sidorenko ${ }^{c}$
}

Institute of Management and Informatics, Ural State University of Economics, Ekaterinburg 620144, Russian Federation

aapla@usue.ru, bcmb_8@mail.ru, cmichail_tsr@mail.ru

Keywords: investment policy, industrial parks, investment attractiveness, efficiency of investment activities, investment projects, investment climate.

\begin{abstract}
The article presents the results of an empirical study comparing different tools to increase regional investment attractiveness. As the main indicators of the valuation, the amount of attracted investments and the number of newly created jobs are used. As a basis for the analysis, more than 200 infrastructure facilities were selected: special economic zones, industrial parks, technoparks, etc. The results of the research show that for the Russian regions the greatest effect is provided by the creation of industrial parks, since the concept itself provides for investors greater complexity and controllability of the elements of infrastructure at these sites.
\end{abstract}

\section{Introduction}

Today, it becomes more and more obvious that in the conditions of limited labor, financial, infrastructural and other resources, Russian regions are openly competing for the possibility of using them. Questions of competition between regions were first raised in the works of Krugman P. [1], Porter M. [2], the issues of the growth of the interrelation between production and regional development by Waits M.J. [3], Phelps N.A. and Fuller C. [4]. However, up to now leading scientists have been arguing about the need and ways to assess the competitiveness of economic systems, including. territorial.

This problem requires a proposal from the regional government authorities that the best conditions for investing and doing business, ensuring favorable conditions for entering the markets for new firms capable of creating new jobs, and realizing specific investment projects are in comparison with other regions. At the same time, it should be borne in mind that these decisions are being developed in the context of transition from stimulating anti-crisis programs to strategic and innovative measures, as well as adaptation of the national economic system to slowing the growth of budget revenues.

At the federal level, a whole range of measures aimed at improving the investment climate in the Russian Federation is already being implemented. Such development institutions as the Investment Fund of the Russian Federation, Vnesheconombank, the Federal Fund for the Promotion of Housing Development, the Foundation for Assistance in Housing and Communal Services Reform, etc. have been established and are functioning. The investment institution of the investment commissioner in the Russian Federation and in the federal districts, the direct investment fund for attracting foreign investment in the Russian economy and the Agency for Strategic Initiatives to promote new projects.

The implementation of large-scale investment projects related to the holding in the Russian Federation of the largest international events, including sports, will also significantly upgrade the infrastructure in the regions, improve its quality and accessibility for citizens and businesses [5].

Meanwhile, a special role in improving the investment climate belongs to the constituent entities of Russian Federation. It is at the regional level that specific development problems are solved, pilot projects are implemented, the results, the implementation of which is generalized in the state policy at the federal level [6]. Investments largely determine the economic growth of the region, employment of the population and is an essential element of the base on which its economic development is based. In this regard, it is quite obvious that the effectiveness of the activities of the authorities of the constituent entities of the Russian Federation and local self-government bodies today is assessed, including, 
depending on the success in creating institutional conditions for attracting investors. There is an increase in the stimulating factors in managing the social and economic development of the Russian regions, in particular, the success of the work of the leadership of a particular constituent entity of the Russian Federation will be assessed both by the indicators of the volume of attracted investments and the number of jobs created.

\section{Methodical tools for assessing the effectiveness of investment activities}

To assess the effectiveness of the development and implementation of specific regional investment activities, the authors propose an express methodology presented in Table 1 . In accordance with the provisions of the theory of utility, it is proposed to evaluate the investment project by integrating the main properties of the project from the position of the region into one integral indicator. The utility function is built to obtain a quantitative and comparative evaluation of the value of projects from the position of the region.

Table 1 Express methodology for assessing the effectiveness of the implementation of an investment project

\begin{tabular}{|c|c|c|}
\hline $\begin{array}{l}\text { Indicator } \\
\text { name }\end{array}$ & Formula & Characteristics of indicators \\
\hline Integral coefficient & $C_{\text {int }}=\sqrt{C_{i n v} \times R_{j o b}}$ & $\begin{array}{c}C_{\mathrm{inv}}-\text { Coefficient of investment attraction; } \\
R_{j o b}-\text { Job Creation Ratio. }\end{array}$ \\
\hline $\begin{array}{l}\text { Coefficient of } \\
\text { investment } \\
\text { attraction }\end{array}$ & $C_{\text {inv }}=\frac{I n v_{\text {project }} \times 100 \%}{I n v_{\text {total }}}$ & $\begin{array}{c}\text { Inv } v_{\text {project }} \text { - the amount of investments involved in } \\
\text { the creation and development of the project; } \\
\text { Inv } v_{\text {total }} \text { - total investments in the region for the } \\
\text { same period. }\end{array}$ \\
\hline Job Creation Ratio & $R_{j o b}=\frac{Q_{j o b} \times 100 \%}{Q_{\text {unemployed }}}$ & $\begin{array}{l}Q_{j o b}-\text { the number of jobs created during the } \\
\text { project; } \\
Q_{\text {unemployed }}-\text { is the number of unemployed in the } \\
\text { region. }\end{array}$ \\
\hline
\end{tabular}

The integral indicator assumes a generalized numerical characteristic of the effectiveness of the implementation of the investment project from the position of the region.

\section{The Results of using the indicator}

In the course of the study, the authors evaluated a wide range of institutions that contribute to improving the investment climate and increasing the investment attractiveness of the region. Figure 1 shows the results of the study.

The analysis allowed to make a comparative assessment of the effectiveness of creating certain types of infrastructure objects from the position of the regional economy. Among them: the creation of ready-made industrial sites - industrial parks, business incubators, technology parks and special economic zones. The results of the analysis demonstrate that the greatest complexity of work with residents and the manageability of support elements is achieved when creating industrial parks.

This fact is confirmed by the positive experience of a number of Russian regions - Kaluga, Leningrad, Lipetsk, Moscow, Sverdlovsk regions, the Republic of Tatarstan, etc. So, for example, the Kaluga region has already formed a positive image in attracting investors and implementing projects. The region is distinguished by a fairly convincing proposal of its investment opportunities. The presence of industrial parks in the Kaluga region helps the investor to build and start production exactly at the time that he planned, and sometimes even earlier [7].

The investment policy of the Leningrad region is based on the use of competitive advantages of the geopolitical position of the region, its natural and resource, economic and scientific and technical 
potential, as well as favorable tax regime allowing to attract over six billion dollars of investment per year to the region, create dozens of new enterprises and provide a permanent the growth of tax revenues to the budget. As a result, a stable base for economic growth of the region has been created in the Leningrad region, new industrial enterprises are developing, new technologies are being introduced, and, very importantly, qualified workplaces are being created. In the region, the largest projects, not only on Russian, but also on European scale, are successfully implemented. Thus, the largest tobacco company in the world - Philip Morris, having built a cigarette factory with an investment of \$ 300 million, increased its investment to $\$ 630$ million. The world famous Ford company built a car manufacturing plant in the Leningrad region with an investment volume of \$ 150 million [8].

The success of the Moscow region is largely due to the use as one of the main tools of investment programs of the Government of the Moscow Region, implemented through extrabudgetary sources. Among the major investment projects in the region are such industrial parks as Davydovskoye (the volume of disbursed investments amounted to 3 billion 584 million rubles), Severny (1 billion 799 million rubles), Volokolamsky, Davydkovsky, as well as a multifunctional park "White Rust" (1 billion 280 million rubles, attracted more than 15 residents). It should also be noted that the number of proposals of investors and administrations of municipalities in the Moscow region to create additional industrial districts continues to grow.

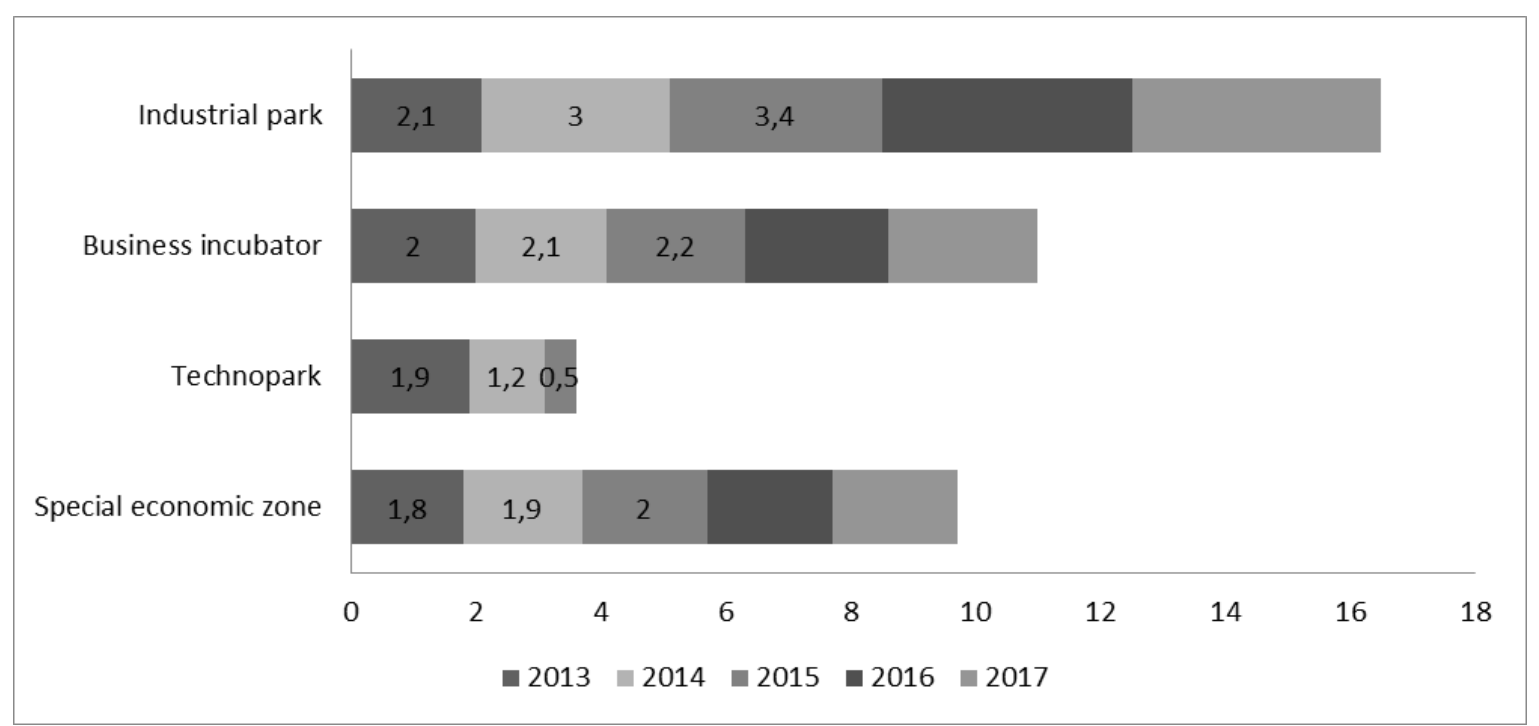

Fig. 1 Comparative evaluation of investment-oriented activities based on the proposed indicator for various development institutions for 2013-2017

The Republic of Tatarstan is by right one of the most economically developed regions, one of the leaders among all subjects of the Federation in terms of "density" and "saturation" of the regional innovation system. This is largely due to the fact that the republic has a number of competitive advantages and an effective model of government incentives for investment and innovation. This model combines both direct and indirect methods of encouraging investment in innovation. These include regional investment legislation and investment programs, exemption from payment and benefits for regional taxes, targeted subsidies, grants, collateral for attracted investments, preferential terms for the use of property, etc.

\section{Conclusion}

Analysis shows that up to the present time, despite the efforts made by the state authorities, such factors of growth in investment attractiveness as a natural resource, economic, personnel and investment potential in Russian territories have not been sufficiently exploited. At the same time, the current situation is due to both objective and subjective reasons that are typical for a single territory. So, among the main problems of investment attractiveness are the presence of administrative and 
institutional barriers, as well as the low level of infrastructure development and the low level of its accessibility.

We should also remember the specifics of the Russian regions. Due to objective laws of spatial development of the Russian Federation, today it is necessary to conduct a differentiated state policy to increase investment attractiveness in relation to regions with different levels and conditions of social and economic development.

In addition, characteristic of the Russian economic space is also the fact that, in principle, regions comparable in terms of their development demonstrate absolutely different dynamics, sometimes even in different directions.

Proceeding from the foregoing, the following conclusion seems reasonable: each region striving to occupy a worthy place in the competitive struggle, it is extremely important to develop its own model for reducing costs and investment risks, supporting investment projects and infrastructure development, thus enabling regional authorities to lay a powerful strategic foundation and guarantee the further well-being of its territory.

\section{References}

[1]. Krugman P. The current case for industrial policy. In D. Salvatore (Ed.), Protectionism and world welfare. New York: Cambridge University Press. (1993), pp. 160-179.

[2]. Porter M. Clusters and competition: New agendas for companies, governments, and institutions. In M. Porter, On competition. Boston: Harvard Business School Press. (1998), pp. 197-287.

[3]. Waits M. J. State of cluster-based economic development in Arizona. In R. Breault (Ed.), Global networking of regional optics clusters. Denver, CO: International Society for Optical Engineering. (1996), pp. 1-10.

[4]. Phelps. N.A., Fuller C. Multinationals, intracorporate competition, and regional development Economic geography vol. 76 (2000) No. 3, p. 224.

[5]. Kokovikhin A. Yu., Ogorodnikova E. S., Williams, D., et al. Institutional factors in the evaluation by the entrepreneur of municipality investment climate. Economy of region. Vol. 13 (2017) No. 1, pp. 80-92.

[6]. Ermoshina, T., V; Yulenkova, I. B. Financial support of investment process in Russian economy in conditions of limited resources. Proceedings of the International Conference on Trends of Technologies and Innovations in Economic and Social Studies (TTIESS). AEBMR-Advances in Economics Business and Management Research. Vol. 38 (2017), pp. 157-162.

[7]. Sandler D. G., Kuznetsov P. D. Industrial Parks In Russia: Conceptual Development Of The Project. Economy of region Vol. 1 (2015), p. 76.

[8]. Kotlyarova S.N., Lavrikova Yu.G., Averina L.M. The Role of Industrial Production Localization in the Import Substitution Policy. Economic and social changes-facts trends forecast. Vol. 53 (2017) No. 5, pp. 115-127. 